Edith Cowan University

Research Online

Research outputs 2014 to 2021

2020

Co-occurrence across time and space of drug- and cannabinoidexposure and adverse mental health outcomes in the National Survey of Drug Use and Health: combined geotemporospatial and causal inference analysis

\author{
Albert Stuart Reece \\ Edith Cowan University \\ Gary Hulse \\ Edith Cowan University
}

Follow this and additional works at: https://ro.ecu.edu.au/ecuworkspost2013

Part of the Medicine and Health Sciences Commons

10.1186/s12889-020-09748-5

Reece, A. S., \& Hulse, G. K. (2020). Co-occurrence across time and space of drug-and cannabinoid-exposure and adverse mental health outcomes in the National Survey of Drug Use and Health: combined geotemporospatial and causal inference analysis. BMC public health, 20(1), Article 1655. https://doi.org/10.1186/s12889-020-09748-5 This Journal Article is posted at Research Online. https://ro.ecu.edu.au/ecuworkspost2013/9188 


\title{
Co-occurrence across time and space of drug- and cannabinoid- exposure and adverse mental health outcomes in the National Survey of Drug Use and Health: combined geotemporospatial and causal inference analysis
}

\author{
Albert Stuart Reece ${ }^{1,2^{*}}$ (DD and Gary Kenneth Hulse ${ }^{1,2}$
}

\begin{abstract}
Background: Whilst many studies have linked increased drug and cannabis exposure to adverse mental health $(\mathrm{MH})$ outcomes their effects on whole populations and geotemporospatial relationships are not well understood.

Methods: Ecological cohort study of National Survey of Drug Use and Health (NSDUH) geographically-linked substate-shapefiles 2010-2012 and 2014-2016 supplemented by five-year US American Community Survey. Drugs: cigarettes, alcohol abuse, last-month cannabis use and last-year cocaine use. MH: any mental illness, major depressive illness, serious mental illness and suicidal thinking. Data analysis: two-stage, geotemporospatial, robust generalized linear regression and causal inference methods in $\mathrm{R}$.
\end{abstract}

Results: 410,138 NSDUH respondents. Average response rate 76.7\%. When drug and sociodemographic variables were combined in geospatial models significant terms including tobacco, alcohol, cannabis exposure and various ethnicities remained in final models for all four major mental health outcomes. Interactive terms including cannabis were related to any mental illness ( $\left(\right.$-estimate $=1.97$ (95\%C.I. 1.56-2.37), $P<2.2 \times 10^{-16}$ ), major depressive episode ( $\beta$-estimate $=2.03(1.54-2.52)$, $\left.P=3.6 \times 10^{-16}\right)$, serious mental illness (SMI, $\beta$-estimate $\left.=2.04(1.48-2.60), P=1.0 \times 10^{-12}\right)$, suicidal ideation ( $\beta$-estimate $=1.99$ $\left.(1.52-2.47), P<2.2 \times 10^{-16}\right)$ and in each case cannabis alone was significantly associated (from $\beta$-estimate $=-3.43(-4.46-$ $-2.42), P=3.4 \times 10^{-11}$ ) with adverse $\mathrm{MH}$ outcomes on complex interactive regression surfaces. Geospatial modelling showed a monotonic upward trajectory of SMI which doubled (3.62 to 7.06\%) as cannabis use increased. Extrapolated to whole populations cannabis decriminalization $(4.26 \%,(4.18,4.34 \%))$, Prevalence Ratio $(P R)=1.035(1.034-1.036)$, attributable fraction in the exposed (AFE) $=3.28 \%(3.18-3.37 \%), P<10^{-309}$ and legalization $(4.75 \%(4.65,4.84 \%), P R=1.155(1.153-1.158)$, $\mathrm{AFE}=12.91 \%(12.72-13.10 \%), \mathrm{P}<10^{-300}$ ) were associated with increased SMI vs. illegal status (4.26, (4.18-4.33\%)).

\footnotetext{
* Correspondence: stuart.reece@bigpond.com

${ }^{1}$ Department of Psychiatry, University of Western Australia, Crawley, Western Australia, Australia

${ }^{2}$ Department of Health Sciences, Edith Cowan University, Joondalup, Western Australia, Australia
}

(c) The Author(s). 2020 Open Access This article is licensed under a Creative Commons Attribution 4.0 International License, which permits use, sharing, adaptation, distribution and reproduction in any medium or format, as long as you give appropriate credit to the original author(s) and the source, provide a link to the Creative Commons licence, and indicate if changes were made. The images or other third party material in this article are included in the article's Creative Commons licence, unless indicated otherwise in a credit line to the material. If material is not included in the article's Creative Commons licence and your intended use is not permitted by statutory regulation or exceeds the permitted use, you will need to obtain permission directly from the copyright holder. To view a copy of this licence, visit http://creativecommons.org/licenses/by/4.0/. The Creative Commons Public Domain Dedication waiver (http://creativecommons.org/publicdomain/zero/1.0/) applies to the data made available in this article, unless otherwise stated in a credit line to the data. 
(Continued from previous page)

Conclusions: Data show all four indices of mental ill-health track cannabis exposure across space and time and are robust to multivariable adjustment for ethnicity, socioeconomics and other drug use. MH deteriorated with cannabis legalization. Cannabis use-MH data are consistent with causal relationships in the forward direction and include dose-response and temporal-sequential relationships. Together with similar international reports and numerous mechanistic studies preventative action to reduce cannabis use is indicated.

Keywords: Cannabis, Cannabinoid, $\Delta$ 9-tetrahydrocannabinol, Cannabigerol, Mental illness, Major depressive illness, Suicidal ideation, Pathways and mechanisms

\section{Background}

It is widely understood that the use of addictive substances impacts mental health adversely. Cannabis use has been linked with numerous adverse mental health outcomes including reduced educational achievement $[1,2]$, increased criminal involvement [3], reduced accomplishment of adult goals (education, employment, stable long term relationships) [4], depression [5-7] bipolar disorder [8-10], anxiety [7, 11-13], suicidality [7, 10, 14, 15], schizophrenia, psychosis [16-23] and other drug use [24].

Indeed one notes that the existence and mission of the US Substance Abuse and Mental Health Services Administration (SAMHSA) aims to minimize the incidence of both substance abuse and mental ill-health in order to advance the behavioural health of the nation [25] and that of the National Institute of Drug Abuse is not dissimilar [26]. As such it is widely perceived that substance use may negatively impact major mental health outcomes. This issue was clearly crystallized by the Director of the SAMHSA, Dr. Elinore McCantz-Katz in her presentation of the 2017 National Survey of Drug Use and Health (NSDUH) results which showed in a nationally representative sample of 18-25 year old young adults from 2008 to 2017, a doubling of serious mental health issues from 3.8 to $7.5 \%$ and of suicidal plans from 2.0 to $3.7 \%$ in the context of past month cannabis use rates rising from 17.3 to $22.1 \%$ but falling use of tobacco and alcohol products and low use rates of opioids and cocaine use [27].

This implies that the unbridled adoption of the widespread use of new addictive psychoactive substances may potentially have far-reaching psychological implications with possible impacts at the public health level. It would appear inevitable that in view of the known adverse effects of cannabis on mental health at the molecular, cellular and epidemiological levels [28-33] its widespread deployment in the community would necessarily be causally linked with numerous indices of deteriorating mental health. This was of particular concern in USA in view of the appalling deterioration in the mental health of young adults described in detail by SAMHSA (above paragraph).
In the present context this applies particularly to cannabis use which, since the takeover of various cannabis operations by major tobacco corporations, seems poised at the threshold of major commercialization and global launch by utilizing the global reach and marketing platform of what is popularly known as the "Big Tobacco" industry. Notwithstanding its representation in popular culture as a relatively harmless "soft" drug, cannabis use has been shown to be linked with a variety of negative mental health outcomes including cannabis dependency and use disorder, an impaired lifetime trajectory and fulfilment of adult goals, an amotivational state, an increased incidence of graduation to use of other addictive agents, depression, anxiety, bipolar disorder, schizophrenia and suicide [2, 4, 17, 24, 28, 34-40].

Such being the case one would expect patterns of mental health to follow cannabis use across both time and space. The NSDUH conducted annually by SAMH SA is a globally unique drug dependency and mental health research resource which allows investigation of both substance use and mental health at relatively high spatial and temporal resolution. Its availability publicly together with the presence of high definition substate shapefiles which link these parameters geospatially at defined time points, and which can be matched with other datasets such as those available through the US census, presents a globally unique opportunity to conduct an important public health investigation of these potentially related trends.

The hypothesis driving the present ecological epidemiological investigation was firstly, that substance use and mental health are linked in a formally demonstrable manner, and secondly, that increasing rates of cannabis use would be reflected at the level of population health trends in a robust manner which persisted after adjustment for other common sociodemographic variables. These hypotheses was formulated prior to study commencement. We considered that it was important to use modern geospatiotemporal regression and the tools of formal causal inference in investigating these questions and associations, and in particular in assessing the potentially causal nature of the relationship. A corollary of this is that one might expect metrics of mental health to 
be worse in states where cannabis is legal. This hypothesis was also tested.

Whilst a link between substance use and adverse mental health is well described in various clinical contexts what is not clear is the extent to which the mental health of whole populations is impacted with particular reference to trends across both space and time and considerations of a putatively causal relationship. It was these gaps that the present research aimed to fill.

It follows that such an enquiry is particularly timely at the present juncture given what appears to be a clear and present international threat to global mental health. On the international scene cannabis is clearly enjoying a modern renaissance under its falsely reassuring image as a low toxicity compound. If concerning trends can be identified and described in USA then it follows that such concerns are likely to apply elsewhere, most particularly if the causal nature of the relationship could be demonstrated at the population health level. For these reasons the present study was timely and important not only for the health of Americans, but indeed to protect the global community of nations.

\section{Methods}

Data

NSDUH Data on drug use by area was downloaded from the publicly available NSDUH SAMHSA substate shapefiles for 2010-2012 and 2014-2016 [41, 42]. A NSDUH shapefile for 2012-2014 exists but as it substantially overlaps the other two its inclusion would significantly complicate the analysis so this has not been used. This implies that data for 2015 was not used in the present analysis. On occasion the triennia were referred to by their middle year, hence 2011 and 2015. Over 405,000 participants were surveyed across the 6 years. The 2014-2016 shapefile divides the USA into 395 substate areas based either on county or congressional district boundaries. The four drugs of interest were last month cigarette use, past year alcohol abuse or dependence, last month cannabis use, and last year cocaine use which are abbreviated to cigmon, abodalc, mrjmon and cocyr in the NSDUH documentation. These drugs were treated as covariates for cannabis use. Unfortunately no consistent nomenclature for opioid exposure could be identified across both shapefiles. The four mental illnesses mentioned in the NSDUH shapefiles are any mental illness in the past year, major depressive episode, serious mental illness in the past year and suicidal thinking whose NSDUH abbreviations are amiyr, mde, smiyr and suithyr. Serious mental illness is defined as a "mental, behavioural or emotional disorder resulting in severe functional impairment which substantially interferes with one or more major life activities" and includes the diagnoses of major depression, bipolar affective disorder and schizophrenia [43].US Census Bureau County data on ethnicity and median household income (MHY) was downloaded from the via the tidycensus package in $R$ using shapefiles from the $\mathrm{R}$ package tigris. Sociodemographic data was derived from the 5 year American Community Survey (ACS, "acs5") conducted by US Census. The two NSDUH shapefiles were centred on 2011 and 2015 so they were matched to the ACS 2009-2013 and ACS 2013-2017 respectively. Each respective ACS shapefile was then interpolated into the substate area definitions provided by SAMHSA. The two combined NSDUH shapefiles were then combined together with the 2014-2016 NSDUH shapefile as the standard (or "target") file. Data for Alaska and Hawaii was treated separately and then added in to the final shapefile and elided (moved) into their appropriate positions for illustration purposes.

Data on the concentration of cannabinoids in federal seizures of cannabis to 2011 has been published [44, 45]. In 2011 the concentration of tetrahydrocannabinol (THC) was $11 \%$ and it has been increasing by about $1 \%$ annually. Projected forwards this provides an estimate of $15 \%$ in 2015.

\section{Statistics}

The analysis was conducted in January 2020. Data was processed in " $R$ " from CRAN using several packages including tidyverse, tidycensus, tigris, sp., sf, spdep and splm. Graphs and maps were drawn in ggplot2. Hawaii and Alaska were elided for illustration in sp. (spatial modelling), converted back to sf (simple features) and rendered in the USA contiguous Albers Equal Area Conical projection EPSG:102003 as in the R package albersusa. Disparate geographical boundaries were conformed using R::areal. Statistical model reduction from first to final models was by the classical technique of sequential elimination of the least significant term until only significant terms remain.

The formal analysis of spatially distributed data is not methodologically trivial but requires dedicated methods in order to account for the spatial relationships by which many variables interact and are dependent on each other. In 1970 Waldo Tobler described the first law of geography when he noted that things nearby interact more than things far away [46]. It is important to take this spatial autocorrelation into account when analyzing spatially distributed variables. The package splm in the " $R$ " computing environment is purpose built for such applications. In particular it includes the spatial panel generalized method of moments (spgm) function which is ideally suited to short panel datasets such as this one and the spatial panel random error maximum likelihood (spreml) function which includes sophisticated methods to account for various spatial lag and error structures. 
Both techniques allow the use of instrumental variables. Thus both techniques have been applied to this dataset.

Geospatiotemporal data processing was done using the "R" package splm (spatial panel linear modelling) with the spatial panel generalized method of moments (spgm) function as it is ideally suited to short panel data such as this and also with the recent spml refinement spreml (spatial panel random error maximum likelihood) function which incorporates sophisticated modelling of error and autocorrelation structures. The standard spgm model was spatially lagged, used the full weights method, a generalized two-step least squared estimation method, spatial error and lagged the instrumental variables. Instrumental variables were the local cannabis ethnic potency index (LCEPI) defined below. For spreml models the full model was used including spatial lagging, spatial errors of Kapoor, Kelejian and Prucha [47], autocorrelation order 1 errors and the same ethnic instrumental variables as above. Spatial errors and spatial weights were calculated using the spdep::poly2nb function and these data were updated to include conceptual links from the Hawaiian islands to south-eastern California and from Alaska to Washington state and Oregon.

Modelling of fitted values was done by matrix multiplication of mean, minimum and maximum values into model coefficients as indicated. Analysis of the impact of cannabis legal status at state level was undertaken from the state-based NSDUH data table ("state_saes_final.sas7bdat") supplemented by cannabis legal status defined from an internet search. Data was manipulated with dplyr and the resulting two-by-two tables were analyzed in epiR.

\section{Causal inference analysis}

Inverse probability weighting was conducted for the whole sample using the $\mathrm{R}$ package ipw. This transforms our study from merely ecological and observational to a pseudo-randomized design where causal inferential relationships can properly be assigned. These weights were then entered into robust generalized linear regression using the $R$ package survey with substate region as the identifying variable. In order to calculate a model standard deviation the weights were also utilized in mixed effects regression using the $\mathrm{R}$ package nlme again with substate region as the grouping variable.

The e-Value is a new index which was recently defined [48] which quantitates the degree of association with both the exposure and the outcome which would be required of an unmeasured confounding variable to explain away the observed significant finding [48-53]. It is presented on the risk ratio scale. Research literature commonly contains e-Values of 1.25 and above [52]. eValues were computed from relative risks and regression coefficients using the $\mathrm{R}$ package EValue. $P<0.05$ was considered significant throughout.

\section{Data availability statement}

Data including shapefiles and $R$ programming script is made publicly available on the Mendeley Data Archive at this URL:

https://doi.org/10.17632/gyckst6rx8.1. The original SAMHSA shapefiles may be found at https://www. samhsa.gov/data/report/2014-2016-nsduh-substate-region-shapefile and https://www.samhsa.gov/data/report/2012-2014-nsduh-substate-region-shapefile.

\section{Ethics}

Ethical approval for this study was provided by the University of Western Australia Human Research Ethics Committee 08/01/2020 (No. RA/4/20/4724).

\section{Results}

Of 534,000 individuals approached 410,138 responded to the six NSDUH surveys, a completion rate of $76.7 \%$. Data for the 2 years 2011 and 2015 are listed as median and interquartile ranges and compared nonparametrically in Supplementary Table 1.

Figure 1 shows the rates of mental illness for the four NSDUH-defined mental health disorders included in the SAMHSA substate shapefiles of any mental illness, major depressive episode, serious mental illness and suicidal thinking.

Figure 2 shows map-graphically the distribution of the use of various drugs across USA in the two NSDUH triennia.

Figure 3 shows the rates of the four mental illness syndromes by drug use at state level. The slope (as $\beta$ estimates) and significance of these regression lines is shown in Supplementary Table 2. The slopes for three of the lines is significant.

Supplementary Fig. 1 shows the ethnic composition of USA for the two periods.

Supplementary Fig. 2 shows the rate of median household income in the USA in the two periods 2010-2012 and 2014-2016.

National level NSDUH data make it clear that there are considerable differences between various ethnicities in drug use and especially daily / near daily cannabis use. These can be averaged out by ethnicity to derive a cannabis use frequency index at the national level. It is likely that regional data also impacts cannabis use by ethnic populations so an index of this was derived by multiplying the local monthly cannabis use by the national ethnic near daily cannabis use to derive a local cannabis ethnic daily index (LCEDI) at state level. Since the THC concentration of cannabis has also been increasing the LCEDI can in turn be multiplied by the 


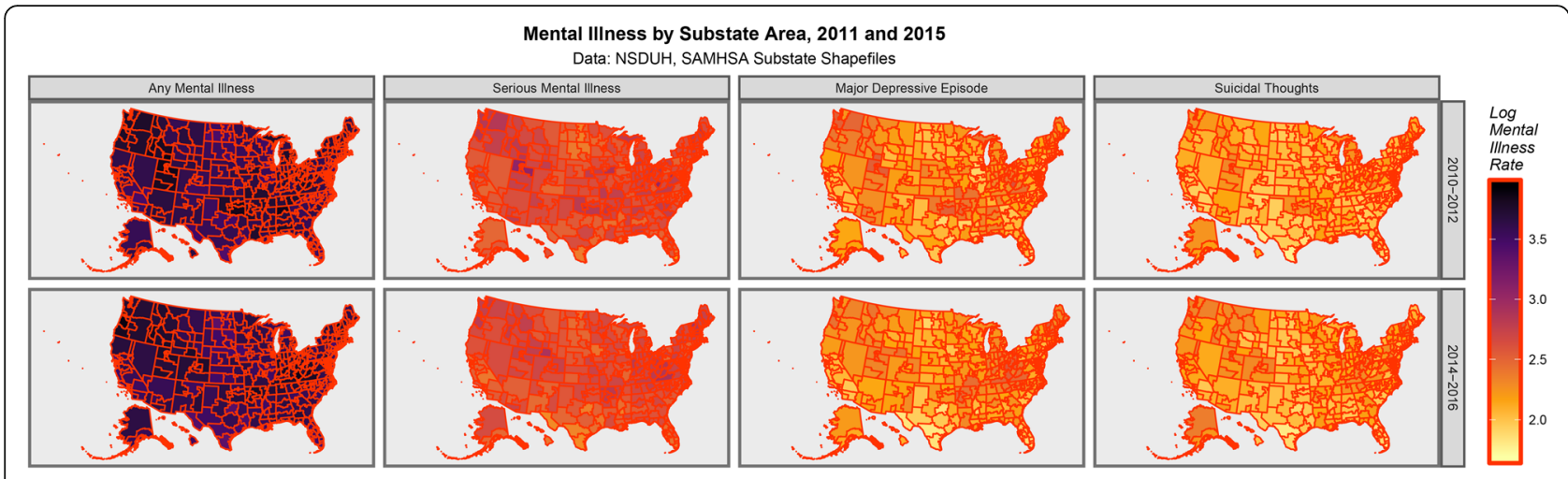

Fig. 1 Mental Illness across USA by substate area. Data from NSDUH Shapefiles

THC content to produce a local cannabis ethnic daily potency index (LCEDPI) of local ethnic exposure to cannabinoids. This LCEDPI index may also be referred to as an "Ethnic score" and it has been used as an important instrumental variable controlling for environmental cannabinoid exposure arising from the sociocultural environment rather than any intrinsic ethnic risk propensity (such as pharmacogenomic susceptibilities). The various LCEDI and LCEDPI are listed in Supplementary Table 3 and illustrated in Supplementary Figs. 3 and 4 . Supplementary Fig. 5 shows the relative rise in these indices from the 2010-2012 baseline and the relative rise comparable to the mean rise by ethnicities.

First degree edge and corner ("queen") spatial weights were calculated between substate areas by R::spdsep:: poly2nb and updated for Alaska, Hawaii and Richmond Island (in New York) as shown in Supplementary Fig. 6A, with final results as shown in Supplementary Fig. 6B.

Supplementary Table 4 presents the spgm results when serious mental illness is regressed against each of drugs, median household income, and ethnicity variables separately with the ethnic LCEPI included as instrumental variables. As noted, only the drug related variables are significant. Terms including cannabis are significant (from $\beta$-estimate $=0.08$ (95\%C.I. 0.02-0.13), $P=0.009)$. Supplementary Table 5 performs the same task for serious mental illness using spreml regression. The significance level of all terms is increased. Both income and racial composition now become significant. Terms including cannabis are significant (from $\beta$-estimate $=2.34$ (1.71-2.97), $P=1.4 \times 10^{-13}$ ).

All the independent variables were then included in a final spgm model shown in Table 1 for all four mental illnesses listed by SAMHSA. All four described drugs survive model reduction and appear in final models. The table is notable for the high level of significance of many drugs including terms involving cannabis (from $\beta$ estimate $\left.=1.74,(0.97,2.51), P=9.9 \times 10^{-6}\right)$. Income and ethnic factors do not survive model reduction. Hence final models include drug related factors only.

Table 2 presents results from a similar exercise applying the advanced techniques of spreml spatial regression. Again all four drugs are included at high level of significance. Terms including cannabis appear (from $\beta$ estimate $\left.=1.84(0.30,2.39), P \leq 3.0 \times 10^{-11}\right)$ for all four illness syndromes. Terms including cannabis appear (from $\beta$-estimate $=-3.31(2.58,4.04), P \leq 2.2 \times 10^{-16}$ for any mental illness and (from $\beta$-estimate $=2.13(1.63$,

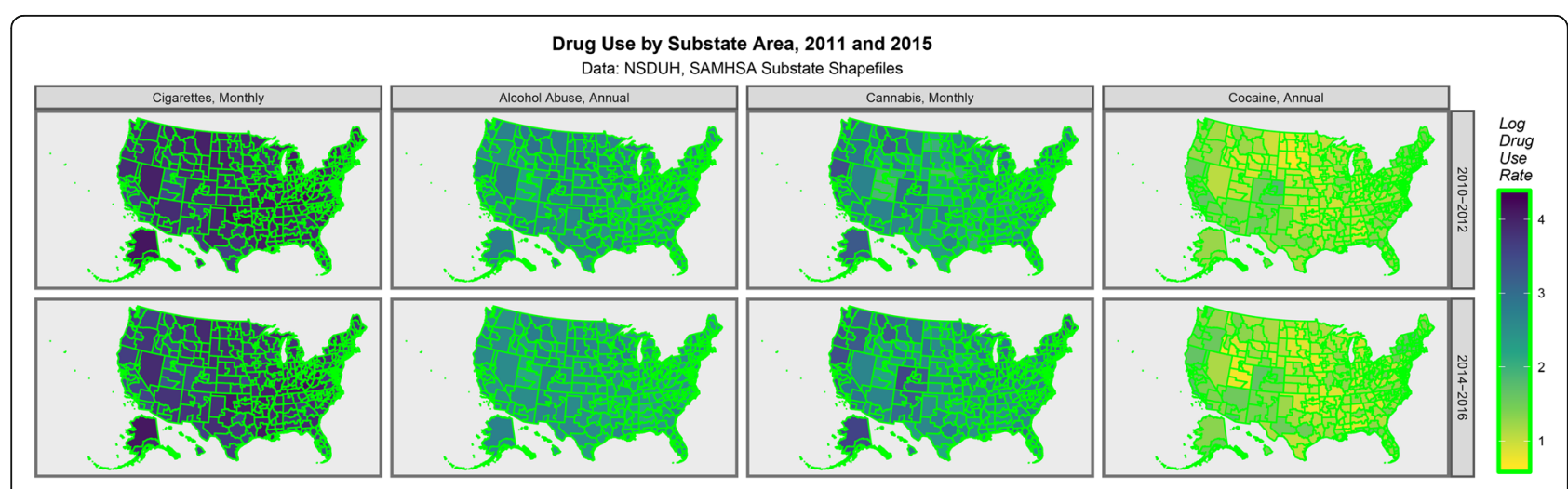

Fig. 2 Drug Use across USA by substate area. Data from NSDUH Shapefiles 


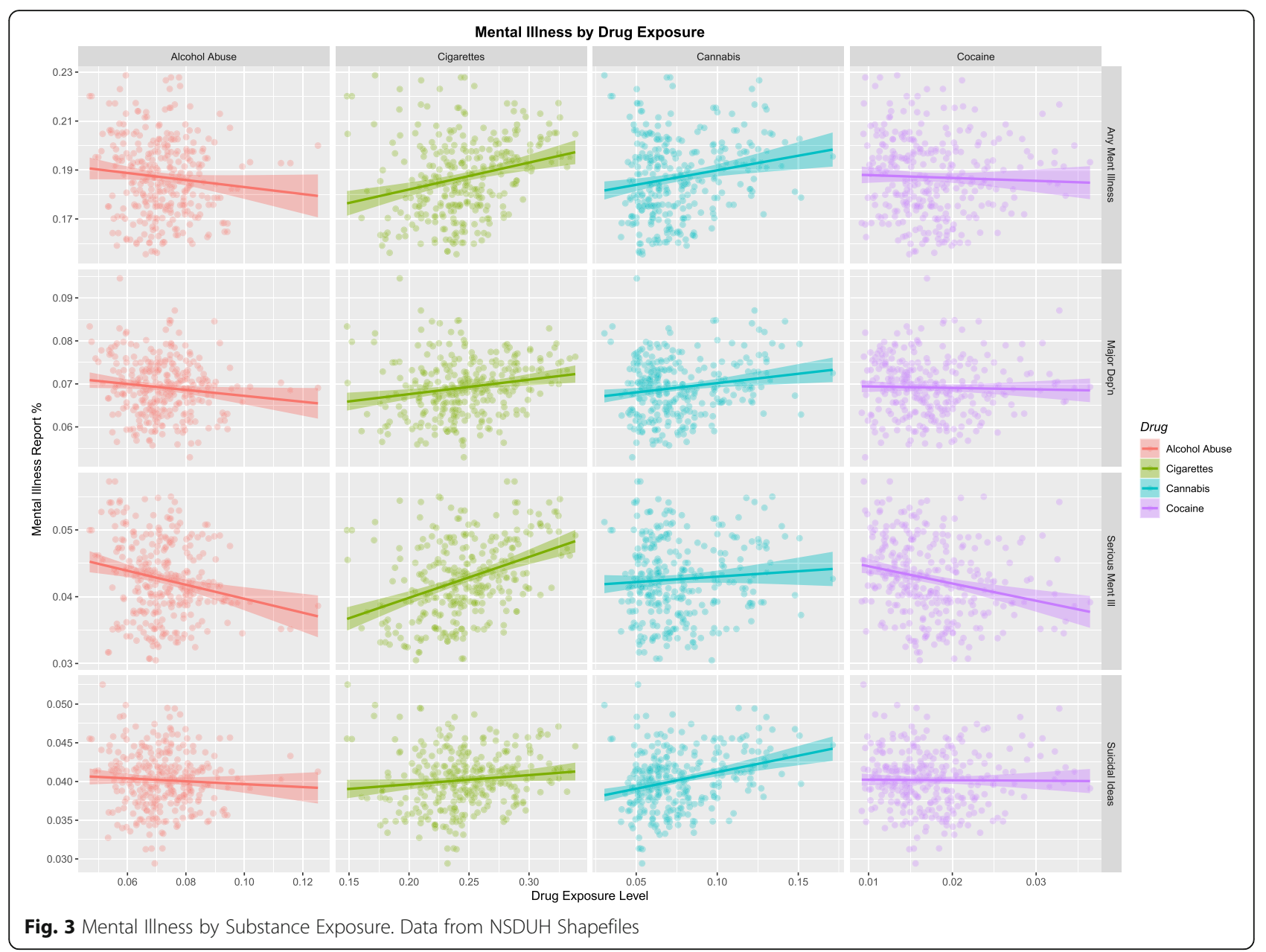

$2.62), \mathrm{P} \leq 2.2 \times 10^{-16}$ ) for major depressive episode. Ethnic factors appear in all models. Median household income only appears in the model for serious mental illness.

As mentioned spreml models give advanced access to the error structure of spatial models. It is therefore mandatory to give careful attention to correct model specification. Supplementary Table 6 shows a selection of the principal error structures and their various specifications. The log maximal likelihood of the models is listed at model optimization, together with the value of the spatial Hausman test comparing each model to the full model. In each case high levels of statistical significance are demonstrated with all $P<2.2 \times 10^{-16}$. These results confirm that the model specification which was presented above, namely the full sem2srre + lag model, is technically correct.

The rates of mental illness can be aggregated into state areas to compare mental illness rates by the legal status of cannabis.

The final spreml model for serious mental illness may be used to compute fitted values. When mean values for tobacco and alcohol abuse together with minimum or maximum values for monthly cannabis use are entered into this model minimum and maximum values for serious mental illness of 3.62 and $7.06 \%$ result (maximum = 1.95 -fold minimum value). Figure 4a shows the modelled rate of serious mental illness as a function of cannabis use decile (Supplementary Table 7).

Data also lend themselves to analysis by the formal techniques of causal inference. Inverse probability weights were calculated as described and entered into robust generalized linear regression equations. The effect of conducting regression procedures with inverse probability weights is to make the sample pseudo-randomly conducted with regard to the exposure of interest, in this case cannabis use, so that the outcome can be properly assessed without the confounding arising from the exposure being nonrandomly distributed across the other covariate exposure groups. The results of final models from additive and interactive models as shown in Table 3. In this Table the dependent variable is serious mental illness rates and the list of covariates includes five racial groups, median household income, ethnic cannabis use scores (LCEDI) and 
Table 1 Spatial panel general method of moments regression - final models

\begin{tabular}{|c|c|c|c|c|c|c|}
\hline \multirow{2}{*}{$\begin{array}{l}\text { General } \\
\text { Instrumental Variables }\end{array}$} & \multicolumn{3}{|l|}{ Parameters } & \multicolumn{3}{|l|}{ Model } \\
\hline & Parameter & Estimate (95\%C.I.) & $P$-Value & Para-meters & Value & $P$-Value \\
\hline & \multicolumn{6}{|l|}{ Any Mental IIIness } \\
\hline NHWhite_Score & \multicolumn{6}{|c|}{ spgm (amiyr Cigarettes * Cannabis * Alcohol_Abuse + Cocaine + Med_HH_Income + 5_Races) } \\
\hline NHBlack_Score & Cigarettes: Cannabis: Alcohol_Abuse & $-0.05(-0.07--0.03)$ & $2.5 \mathrm{E}-05$ & rho & -0.5152 & N/A \\
\hline Hispanic_Score & Cigarettes: Alcohol_Abuse & $0.11(0.06-0.16)$ & 4.6E-05 & $\operatorname{sigma} \wedge 2_{-}$ & 0.003 & N/A \\
\hline NHAsian_Score & Cannabis: Alcohol_Abuse & $1.21(0.61-1.81)$ & $7.9 \mathrm{E}-05$ & lambda & 0.6753 & 1.30E-05 \\
\hline \multirow[t]{8}{*}{ NHAIAN_Score } & Cigarettes: Cannabis & $0.09(0.05-0.13)$ & 0.0001 & & & \\
\hline & Alcohol_Abuse & $-2.43(-3.72--1.14)$ & 0.0002 & & & \\
\hline & Cigarettes & $-0.17(-0.26--0.08)$ & 0.0003 & & & \\
\hline & Cannabis & $-1.99(-3.08--0.9)$ & 0.0004 & & & \\
\hline & Cocaine & $0.05(0.01-0.09)$ & 0.0128 & & & \\
\hline & Median_Household_Income & $-0.03(-0.06-0)$ & 0.0339 & & & \\
\hline & Afr.Am_Pop_Fraction & $0.03(0-0.06)$ & 0.0485 & & & \\
\hline & \multicolumn{6}{|l|}{ Major Depressive Episode } \\
\hline NHWhite_Score & \multicolumn{6}{|c|}{ spgm (mde $\sim$ Cigarettes * Cannabis * Alcohol_Abuse + Cocaine + Med_HH_Income + 5_Races) } \\
\hline NHBlack_Score & Cannabis: Alcohol_Abuse & $1.74(0.97-2.51)$ & $9.9 \mathrm{E}-06$ & rho & -0.6813 & N/A \\
\hline Hispanic_Score & Cigarettes: Cannabis: Alcohol_Abuse & $-0.07(-0.1--0.04)$ & $2.6 \mathrm{E}-05$ & sigma^2 & 0.005 & N/A \\
\hline NHAsian_Score & Cannabis & $-2.98(-4.38--1.58)$ & $2.9 \mathrm{E}-05$ & lambda & 0.8945 & $1.20 \mathrm{E}-04$ \\
\hline \multirow[t]{5}{*}{ NHAIAN_Score } & Alcohol_Abuse & $-3.46(-5.1-1.82)$ & $3.8 \mathrm{E}-05$ & & & \\
\hline & Cigarettes: Cannabis & $0.12(0.06-0.18)$ & $6.3 \mathrm{E}-05$ & & & \\
\hline & Cigarettes: Alcohol_Abuse & $0.13(0.06-0.2)$ & $8.1 \mathrm{E}-05$ & & & \\
\hline & Cigarettes & $-0.23(-0.35--0.11)$ & $2.4 \mathrm{E}-04$ & & & \\
\hline & \multicolumn{6}{|l|}{ Serious Mental Illness } \\
\hline NHWhite_Score & \multicolumn{6}{|c|}{ spgm (smiyr $\sim$ Cigarettes * Cannabis * Alcohol_Abuse + Cocaine + Med_HH_Income + 5_Races) } \\
\hline NHBlack_Score & Cigarettes: Alcohol_Abuse & $0.1(0.03-0.17)$ & 0.0048 & rho & -0.7386 & N/A \\
\hline Hispanic_Score & Cigarettes & $-0.17(-0.29--0.05)$ & 0.0058 & sigma^2 & 0.0055 & N/A \\
\hline NHAsian_Score & Cigarettes: Cannabis: Alcohol_Abuse & $-0.04(-0.07--0.01)$ & 0.0082 & lambda & 0.7722 & 3.37E-07 \\
\hline \multirow[t]{5}{*}{ NHAIAN_Score } & Cocaine & $0.07(0.02-0.12)$ & 0.0087 & & & \\
\hline & Cigarettes: Cannabis & $0.08(0.02-0.14)$ & 0.0092 & & & \\
\hline & Alcohol_Abuse & $-2.14(-3.82--0.46)$ & 0.0126 & & & \\
\hline & Cannabis: Alcohol_Abuse & $0.96(0.17-1.75)$ & 0.0169 & & & \\
\hline & Cannabis & $-1.66(-3.09--0.23)$ & 0.0231 & & & \\
\hline NHWhite_Score & \multicolumn{6}{|l|}{ Suicidal Thoughts Past Year } \\
\hline NHBlack_Score & \multicolumn{6}{|c|}{ spgm (suithyr $\sim$ Cigarettes * Cannabis * Alcohol_Abuse + Cocaine + Med_HH_Income + 5_Races) } \\
\hline Hispanic_Score & Alcohol_Abuse & $-3.05(-4.67--1.43)$ & 0.0002 & rho & -0.6752 & N/A \\
\hline NHAsian_Score & Cannabis: Alcohol_Abuse & $1.37(0.61-2.13)$ & 0.0004 & $\operatorname{sigma\wedge 2_{-}}$ & 0.0051 & N/A \\
\hline \multirow[t]{5}{*}{ NHAIAN_Score } & Cigarettes: Alcohol_Abuse & $0.12(0.06-0.18)$ & 0.0004 & lambda & 0.7757 & $7.96 \mathrm{E}-12$ \\
\hline & Cigarettes: Cannabis: Alcohol_Abuse & $-0.05(-0.08--0.02)$ & 0.0012 & & & \\
\hline & Cigarettes & $-0.19(-0.31--0.07)$ & 0.0016 & & & \\
\hline & Cannabis & $-2.18(-3.55--0.81)$ & 0.0019 & & & \\
\hline & Cigarettes: Cannabis & $0.08(0.02-0.14)$ & 0.0037 & & & \\
\hline
\end{tabular}

\section{Abbreviations}

5_Races: Caucasian-American, African-American, Hispanic-American, Asian-American, NHAIAN

Technical Notes:

phi:- Idiosyncratic component of the spatial error term

psi:- Individual time-invariant component of the spatial error term

rho:- Spatial autoregressive parameter

lambda:- Spatial autocorrelation coefficient 
drug use variables for cigarettes, binge alcohol, monthly cannabis and annual cocaine. In additive models both cannabis use ( $\beta$-estimate $=-0.43(-0.65--0.21), P=0.0002)$, and Caucasian American cannabis use ( $\beta$-estimate $=0.95$ (0.05-1.85), $P=0.0396)$ survived model reduction and were significant. In models including a four-way cigarette: alcohol:cannabis:cocaine interaction, terms including cannabis were significant from $(\beta$-estimate $=0.12(0.10,0.14)$, $\left.P<10^{-16}\right)$.

In inverse probability weighted mixed effects additive and interactive models with the same list of dependent variables and predictive covariates, terms including cannabis were again significant (from $\beta$-estimate $=0.11$ $(0.07,1.15), 1.5 \times 10^{-5}$; Supplementary Table 8$)$.

Sensitivity analyses may be conducted on these odds ratio, mixed effects and geospatial data with many highly significant e-Value results as shown in Supplementary Table 9. The minimal e-values in the geotemporospatial analyses ranged from 3.13 to 2,660,000 (Supplementary Table 9). This compares positively to comments in the literature that e-Values above 1.25 are often quoted in scientific reports [52]. Such elevated values make uncontrolled confounding extremely unlikely and point to a relationship which is truly causal in nature.

When one considers state-based data for the 6 years of the NSUDH shapefiles states with legal cannabis status had an increased rate of serious mental illness (Prevalence ratio $(\mathrm{PR})=1.09$ (95\%C.I. 1.04, 1.13), attributable fraction in the exposed $(\mathrm{AFE})=7.93 \%(4.17$, $11.55 \%)$, attributable fraction in the population $(\mathrm{AFP})=0.70 \%(0.035,1.06 \%)$, Chi.Squ. $=16.25, \mathrm{df}=1$, $\left.P=5.55 \times 10^{-5}\right)$.

Figure $4 \mathrm{~b}$ and Table 4 show the mean rate of serious mental illness as a function of cannabis legal status when NSDUH results are extrapolated onto whole state populations. The values for the Illegal, Medical, Decriminalized and Legal Status are $4.26(4.18,4.34 \%), 4.11$ (4.01, $4.21 \%), 4.01(3.83,4.19 \%)$ and $4.75(4.65,4.85 \%)$ respectively. The notches for the Decriminalized and Legal statuses are noted to not overlap those of the illegal status. Cannabis decriminalization was associated with an increased incidence of serious mental illness $(\mathrm{PR}=1.035$ (1.034, 1.036), $\mathrm{AFP}=3.28 \%(3.18,3.37 \%), \mathrm{AFE}=1.13 \%$ (1.09, 1.16\%), ChiSq. $\left.=4635.1, \mathrm{df}=1, \mathrm{P}<<10^{-300}\right)$, as was cannabis legalization $(\mathrm{PR}=1.155 \quad(1.153,1.158)$, $\mathrm{AFE}=12.91 \%(12.72,13.10 \%), \mathrm{AFP}=0.83 \%(0.82,0.85 \%)$, ChiSq. $\left.=15,015.1, \mathrm{df}=1, \mathrm{P}<<10^{-300}\right)$.

Supplementary Fig. 7 shows the rate of all mental illness syndromes against cannabis legalization status from state based data. The Chi-squared comparisons are shown in Supplementary Table 10. Results for any mental illness and suicidal ideation are both significant $(P=$ 0.0395 and $\mathrm{P}=0.0395)$ are that for serious mental illness approaches significance $(P=0.0654)$.

\section{Discussion}

\section{Main findings}

This study applies current geospatial techniques to the analysis of the four metrics of mental illness spatially described by SAMHSA in recent iterations of NSDUH. Using spatial panel generalized method of moments (spgm) techniques drug-related variables pertaining to tobacco, alcohol, abuse cannabis and cocaine were found to be more significant than socioeconomic and ethnographic factors after correction using estimates for increased local exposure to cannabis in some ethnic groups. For cannabis this included terms significant from $P<10^{-5}$. When more advanced spatial techniques such as the full spatial panel random error maximum likelihood (spreml) models were used these results were confirmed overall and included an increased level of statistical significance for terms including cannabis for all four mental illness metrics from $P<4.0 \times 10^{-11}$. Therefore geospatial techniques increased the precision of the parameter estimates by several orders of magnitude.

It is of interest to consider these findings in the light of the remarks mentioned in the Introductory section relating to the poor and declining mental health of US young adults. First, there is a very obvious association nationally with the dramatic decline in the mental health of young adults in the USA and rising levels of cannabis use in that age demographic [27, 54]. Our results confirm this trend at the higher geospatial resolution of the substate level.

Secondly both study hypotheses are confirmed by study results. All indices of mental health (any mental illness, major depressive illness, serious mental illness and suicidal ideation) are robustly associated with the use of all addictive substances investigated. It is equally clear that the hypothesized relationships between cannabis and all four indices of mental ill-health are not only established, but robust to multivariable adjustment.

Moreover analysis of the data with inverse probability weights in both mixed effects models and robust generalized linear models together with sensitivity analyses indicated that the relationship fulfilled the criteria of causality in each case.

Any mental health issues and suicidal ideation were also shown to be worse in parallel with liberalized cannabis policies. The result for serious mental illness approached significance $(P=0.06)$.

\section{Pathways and mechanisms}

Since the existence of plausible biological pathways explaining a potential causal pathway from cannabis exposure to mental illness is a foundational pillar of causal algorithms such as that of Hill [55] it becomes very important to consider briefly some of the neurotoxic 
Table 2 Spatial panel random error maximum likelihood regression - final models

\begin{tabular}{|c|c|c|c|c|c|c|}
\hline \multirow{2}{*}{$\begin{array}{l}\text { General } \\
\text { Instrumental Variables }\end{array}$} & \multirow{2}{*}{$\begin{array}{l}\text { Parameters } \\
\text { Parameter }\end{array}$} & \multicolumn{5}{|l|}{ Model } \\
\hline & & Estimate (95\%C.I.) & $P$-Value & Para-meters & Value & $P$-Value \\
\hline & \multicolumn{6}{|l|}{ Any Mental Illness } \\
\hline & \multicolumn{6}{|c|}{ spreml (amiyr $\sim$ Cigarettes * Cannabis * Alcohol_Abuse + Cocaine + Med_HH_Income + 5_Races) } \\
\hline NHWhite_Score & Alcohol_Abuse & $-4.19(-5.02--3.36)$ & $<2.2 \mathrm{e}-16$ & phi & 0.008 & 0.9908 \\
\hline NHBlack_Score & Cannabis: Alcohol_Abuse & $1.96(1.55-2.37)$ & $<2.2 \mathrm{e}-16$ & psi & 0.4002 & 0.251 \\
\hline Hispanic_Score & Cannabis & $-3.33(-4.06--2.6)$ & $<2.2 \mathrm{e}-16$ & rho & -0.1507 & 0.3296 \\
\hline NHAsian_Score & Cigarettes: Alcohol_Abuse & $0.15(0.11-0.19)$ & $<2.2 \mathrm{e}-16$ & lambda & 0.2336 & 0.0425 \\
\hline \multirow[t]{10}{*}{ NHAIAN_Score } & Cigarettes & $-0.26(-0.32--0.2)$ & 4.00E-15 & & & \\
\hline & Cigarettes: Cannabis: Alcohol_Abuse & $-0.07(-0.09--0.05)$ & $2.70 \mathrm{E}-15$ & & & \\
\hline & Cigarettes: Cannabis & $0.12(0.09-0.15)$ & $1.20 \mathrm{E}-13$ & & & \\
\hline & Caucasian-Amer.Pop_Fraction & $0.09(0.06-0.12)$ & $1.00 \mathrm{E}-10$ & & & \\
\hline & Median_Household_Income & $-0.09(-0.12--0.06)$ & $1.30 \mathrm{E}-06$ & & & \\
\hline & Hispanic_Pop_Fraction & $-0.01(-0.02-0)$ & 0.0033 & & & \\
\hline & African-Amer._Pop_Fraction & $-0.01(-0.02-0)$ & 0.0062 & & & \\
\hline & Asian_Pop_Fraction & $0.02(0.01-0.03)$ & 0.0131 & & & \\
\hline & \multicolumn{6}{|l|}{ Major Depressive Episode } \\
\hline & \multicolumn{6}{|c|}{ spreml (mde $\sim$ Cigarettes * Cannabis * Alcohol_Abuse + Cocaine + Med_HH_Income + 5_Races) } \\
\hline NHWhite_Score & Cannabis: Alcohol_Abuse & $2.03(1.54-2.52)$ & $3.60 \mathrm{E}-16$ & phi & 0.1573 & 0.9579 \\
\hline NHBlack_Score & Alcohol_Abuse & $-4.14(-5.14--3.14)$ & 4.90E-16 & psi & 0.3124 & 0.8569 \\
\hline Hispanic_Score & Cannabis & $-3.53(-4.41--2.65)$ & $3.80 \mathrm{E}-15$ & rho & -0.3358 & 0.0325 \\
\hline NHAsian_Score & Cigarettes: Alcohol_Abuse & $0.16(0.12-0.2)$ & $1.60 \mathrm{E}-12$ & lambda & 0.3809 & 0.0002 \\
\hline \multirow[t]{10}{*}{ NHAIAN_Score } & Cigarettes: Cannabis: Alcohol_Abuse & $-0.08(-0.1--0.06)$ & $1.90 \mathrm{E}-12$ & & & \\
\hline & Cigarettes & $-0.27(-0.35--0.19)$ & $4.50 \mathrm{E}-12$ & & & \\
\hline & Cigarettes: Cannabis & $0.14(0.1-0.18)$ & $5.70 \mathrm{E}-12$ & & & \\
\hline & Caucasian-Amer._Pop_Fraction & $0.08(0.05-0.11)$ & $2.20 \mathrm{E}-08$ & & & \\
\hline & Hispanic_Pop_Fraction & $-0.02(-0.03--0.01)$ & 0.0003 & & & \\
\hline & African-Amer._Pop_Fraction & $-0.01(-0.02-0)$ & 0.0025 & & & \\
\hline & AIAN_Pop_Fraction & $-0.01(-0.02-0)$ & 0.0085 & & & \\
\hline & Median Household Income & $-0.04(-0.07--0.01)$ & 0.0312 & & & \\
\hline & \multicolumn{6}{|l|}{ Serious Mental IIIness } \\
\hline & \multicolumn{6}{|c|}{ spreml (smiyr Cigarettes * Cannabis * Alcohol_Abuse + Cocaine + Med_HH_Income + 5_Races) } \\
\hline NHWhite_Score & Caucasian-Amer. & $0.21(0.17-0.25)$ & $<2.2 \mathrm{e}-16$ & phi & 0.176 & NA \\
\hline NHBlack_Score & Median Household Income & $-0.22(-0.27--0.17)$ & $<2.2 \mathrm{e}-16$ & psi & 0.153 & NA \\
\hline Hispanic_Score & Alcohol_Abuse & $-4.55(-5.69--3.41)$ & $6.20 \mathrm{E}-15$ & rho & 0.1311 & 0.2141 \\
\hline NHAsian_Score & Cannabis: Alcohol_Abuse & $2.04(1.48-2.6)$ & $1.00 \mathrm{E}-12$ & lambda & 0.0618 & 0.4449 \\
\hline \multirow[t]{8}{*}{ NHAIAN_Score } & Cannabis & $-3.44(-4.46--2.42)$ & $3.40 \mathrm{E}-11$ & & & \\
\hline & Cigarettes:Alcohol_Abuse & $0.17(0.12-0.22)$ & 7.60E-11 & & & \\
\hline & Cigarettes & $-0.27(-0.36--0.18)$ & 1.50E-09 & & & \\
\hline & Cigarettes: Cannabis: Alcohol_Abuse & $-0.08(-0.11--0.05)$ & $2.90 \mathrm{E}-09$ & & & \\
\hline & Cigarettes: Cannabis & $0.13(0.08-0.18)$ & $2.00 \mathrm{E}-08$ & & & \\
\hline & African-Amer._Pop_Fraction & $-0.02(-0.03--0.01)$ & $9.30 \mathrm{E}-06$ & & & \\
\hline & Hispanic_Pop_Fraction & $-0.02(-0.03--0.01)$ & 0.005 & & & \\
\hline & Asian_Pop_Fraction & $0.02(0-0.04)$ & 0.0089 & & & \\
\hline
\end{tabular}


Table 2 Spatial panel random error maximum likelihood regression - final models (Continued)

\begin{tabular}{|c|c|c|c|c|c|c|}
\hline \multirow{2}{*}{$\begin{array}{l}\text { General } \\
\text { Instrumental Variables }\end{array}$} & \multirow{2}{*}{$\begin{array}{l}\text { Parameters } \\
\text { Parameter }\end{array}$} & \multicolumn{5}{|l|}{ Model } \\
\hline & & Estimate (95\%C.I.) & P-Value & Para-meters & Value & $P$-Value \\
\hline & \multicolumn{6}{|c|}{ spreml (suithyr $\sim$ Cigarettes * Cannabis * Alcohol_Abuse + Cocaine + Med_HH_Income + 5_Races) } \\
\hline NHWhite_Score & Alcohol_Abuse & $-4.36(-5.33--3.39)$ & $<2.2 \mathrm{e}-16$ & phi & 0.0225 & 0.9737 \\
\hline NHBlack_Score & Cannabis: Alcohol_Abuse & $1.99(1.52-2.46)$ & $<2.2 \mathrm{e}-16$ & psi & 0.1854 & 0.726 \\
\hline Hispanic_Score & Cannabis & $-3.4(-4.26--2.54)$ & $1.05 E-14$ & rho & -0.1314 & 0.2451 \\
\hline NHAsian_Score & Cigarettes: Alcohol_Abuse & $0.16(0.12-0.2)$ & $6.72 \mathrm{E}-13$ & lambda & 0.2824 & 0.0005 \\
\hline \multirow[t]{8}{*}{ NHAIAN_Score } & Cigarettes & $-0.26(-0.34--0.18)$ & $8.28 \mathrm{E}-12$ & & & \\
\hline & Cigarettes: Cannabis: Alcohol_Abuse & $-0.07(-0.09--0.05)$ & $8.14 \mathrm{E}-11$ & & & \\
\hline & Cigarettes: Cannabis & $0.12(0.08-0.16)$ & $7.25 \mathrm{E}-10$ & & & \\
\hline & Hispanic_Pop_Fraction & $-0.02(-0.03--0.01)$ & 5.53E-08 & & & \\
\hline & African-Amer._Pop_Fraction & $-0.02(-0.03--0.01)$ & 2.89E-07 & & & \\
\hline & Caucasian-Amer._Pop_Fraction & $0.07(0.04-0.1)$ & 1.12E-06 & & & \\
\hline & Asian_Pop_Fraction & $0.03(0.02-0.04)$ & 1.03E-05 & & & \\
\hline & Median Household Income & $-0.08(-0.12--0.04)$ & $5.70 \mathrm{E}-05$ & & & \\
\hline
\end{tabular}

Abbreviations

5_Races: Caucasian-American, African-American, Hispanic-American, Asian-American, NHAIAN

Technical Notes:

phi:- Idiosyncratic component of the spatial error term

psi:- Individual time-invariant component of the spatial error term

rho:- Spatial autoregressive parameter

lambda:- Spatial autocorrelation coefficient

mechanisms which have been described in the published literature. We note that numerous biological pathways have been described linking cannabinoid exposure to neurotoxicity and adverse neuropsychiatric outcomes. Several genetic and epigenetic pathways have been described linking altered dopamine receptor gene and other gene expression with addictive, behavioural and autistic outcomes [56-60]. Cannabinoids have been shown to have adverse effects on neural stem cell activity [61] which negatively and importantly impacts brain
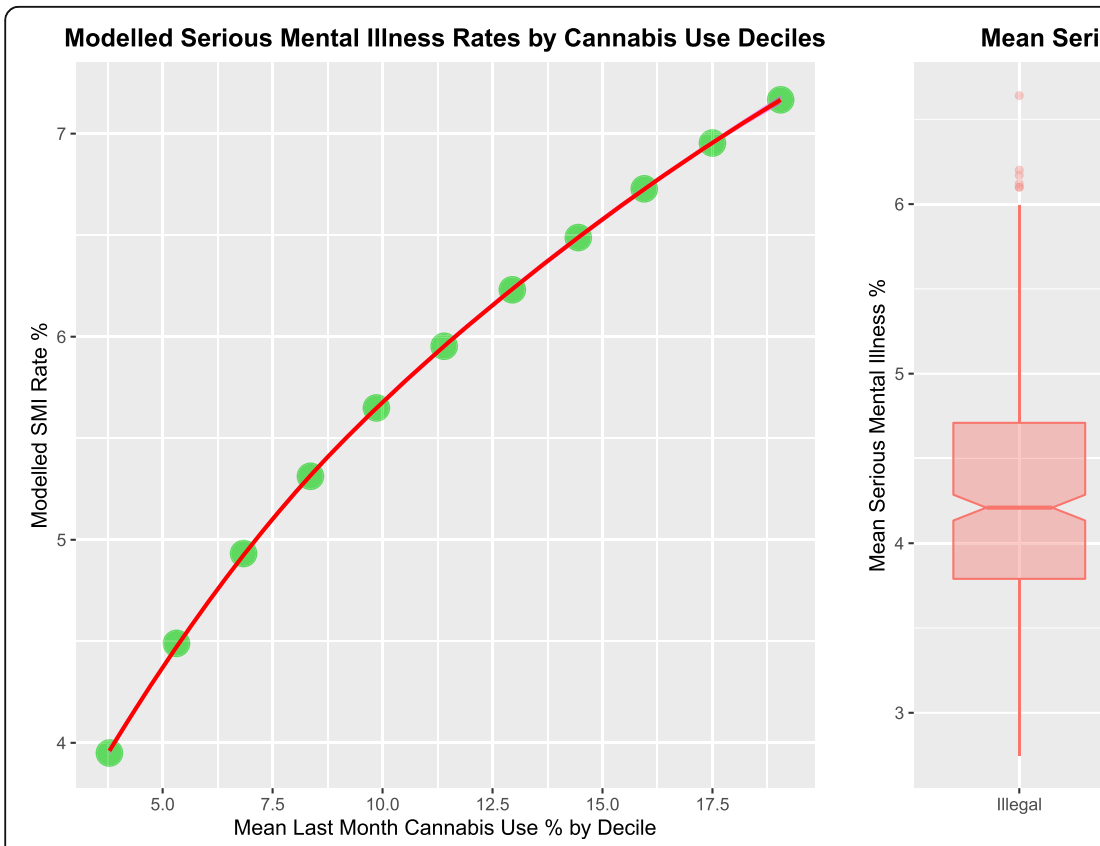

Mean Serious Mental IIIness Rates by Legal Status

Fig. 4 Modelled Relationships and Legal Status. a Serious Mental illness by Rising Cannabis Concentration. b Serious Mental IIIness by Legal Status 
Table 3 Robust Generalized Linear Models Results

\begin{tabular}{|c|c|c|c|}
\hline Parameter & Estimate & C.I. & $P$-Value \\
\hline \multicolumn{4}{|l|}{ Additive Models } \\
\hline Cocaine & 0.27 & $(0.13-0.41)$ & 7.6E-05 \\
\hline Alcohol & 0.09 & $(0.05-0.13)$ & 0.0001 \\
\hline Asian.Am & 0.12 & $(0.06-0.18)$ & 0.0005 \\
\hline Median Household Income & 0.22 & $(0.06-0.38)$ & 0.0041 \\
\hline Cauc.Am.Cannabis & 0.95 & $(0.05-1.85)$ & 0.0396 \\
\hline Cannabis & -0.43 & $(-0.65--0.21)$ & 0.0002 \\
\hline Cigarettes & -0.02 & $(-0.04-0.00)$ & $6.2 \mathrm{E}-05$ \\
\hline Afric.Am & -0.09 & $(-0.13--0.05)$ & $5.8 \mathrm{E}-06$ \\
\hline Hispanic & -0.22 & $(-0.32--0.12)$ & $2.4 \mathrm{E}-06$ \\
\hline \multicolumn{4}{|l|}{ Interactive Models } \\
\hline Cigarettes: Alcohol & 0.06 & $(0.04-0.08)$ & $3.2 \mathrm{E}-26$ \\
\hline Cigarettes: Cannabis & 0.12 & $(0.10-0.14)$ & $1.5 \mathrm{E}-21$ \\
\hline Asian.Am & 0.07 & $(0.05-0.09)$ & 4.0E-19 \\
\hline Alcohol: Cannabis & 0.51 & $(0.39-0.63)$ & $2.7 \mathrm{E}-17$ \\
\hline Alcohol: Cannabis: Cocaine & 0.04 & $(0.02-0.06)$ & $2.2 \mathrm{E}-07$ \\
\hline Afric.Am.Cannabis & -0.19 & $(-0.27--0.11)$ & $3.8 \mathrm{E}-05$ \\
\hline Alcohol: Cocaine & -0.07 & $(-0.11--0.03)$ & $1.9 \mathrm{E}-05$ \\
\hline AIAN.Am & -0.03 & $(-0.03--0.03)$ & 3.7E-07 \\
\hline Cigarettes: Alcohol: Cannabis & -0.02 & $(-0.02--0.02)$ & $2.0 \mathrm{E}-18$ \\
\hline Afric.Am & -0.05 & $(-0.07--0.03)$ & 4.0E-20 \\
\hline Alcohol & -1.41 & $(-1.65--1.17)$ & $2.0 \mathrm{E}-26$ \\
\hline Cigarettes & -0.30 & $(-0.36--0.24)$ & $6.4 \mathrm{E}-28$ \\
\hline Cannabis & -2.75 & $(-3.20--2.30)$ & $3.4 \mathrm{E}-28$ \\
\hline
\end{tabular}

plasticity and brain aging [62]. Cannabinoids can also induce microglial activation and priming [63] which was recently shown to set the brain on a pathway which phenocopies aging [64]. Cannabis exposure has also been shown to age the human organism in a longitudinal study of cardiovascular ageing [64]. Cannabinoids have been shown to decouple both synapses, by negatively impacting the neurexin-neuroligin machinery which scaffolds them [65-68], and grey-white matter coupling [69]. Similarly cannabinoids negatively impact both actin and tubulin expression and dynamics [65] impacting axonal guidance and growth cone mechanics [70] and chromosomal mechanisms, chromosomal segregation and cell division [71]. Cannabis has a negative effect on cell growth, macromolecular synthesis and cell division [72, 73] and adversely affects the slit:robo ratio which controls the hypertrophic exuberant growth of the massive human cerebral cortex [74-76].

It is also important to appreciate that such negative cellular mechanisms have been ascribed to cannabinoids other than simply $\Delta 9$-tetrahydrocannabinol as other chemical moieties, including cannabidiol, cannabichromene and cannabinol have been similarly implicated [77-80]. Indeed it is known that cannabis oil is toxic to many plants including the leaves of Cannabis sativa itself [81].

It is also relevant in this regard that both the epigenetic actions and chromosomal mis-segregation actions of cannabinoids imply not only genotoxicity and epigenotoxicity in the exposed individuals themselves, but also heritable changes to several subsequent generations [82]. As the use of cannabis becomes both more widespread and consumption increases in existing users, cannabinoid exposure will likely become multigenerational and open new routes to cannabinoid-induced heritable neuropsychopathology. This was recently shown for autism in USA [83, 84].

Whilst this study relates to the mental health of adults it has been shown that cannabis use is linked with adverse mental health outcomes in offspring of exposed populations including autism and ADHD-like changes [83-94]. This important datum further amplifies the significance of the present investigation into the crossgenerational context.

Hence taken together these data overall clearly indicate not only that increased cannabis use is causally associated with adverse mental health outcomes at the statistical and epidemiological level, but that multiple biological pathways exist to explain the causal relationship mechanistically. Indeed data in this report indicates that the cannabis-mental illness relationship fulfills all ten of Hill's criteria for causal relationships [55], in addition to the unequivocal demonstration of very close relationships across space and time and the results of the causal inferential techniques employed.

\section{Strengths and limitations}

Our study has a number of strengths and limitations. Its strengths include investigation of what we believe to be

Table 4 Serious mental illness prevalence ratios by legal status

\begin{tabular}{llllll}
\hline Status & $\begin{array}{l}\text { Serious Mental } \\
\text { IIIness Cases }\end{array}$ & $\begin{array}{l}\text { No. Using Cannabis } \\
\text { Last Month }\end{array}$ & Population & $\begin{array}{l}\text { Proportion with Serious } \\
\text { Mental IIIness }\end{array}$ & $\begin{array}{l}\text { Proportion Using } \\
\text { Cannabis Last Month }\end{array}$ \\
\hline Decriminalized & $6,106,622$ & $12,033,634$ & $143,356,702$ & $4.26 \%(4.18,4.34 \%)$ & $8.39 \%$ \\
Illegal & $11,650,796$ & $17,995,589$ & $283,172,529$ & $4.11 \%(4.01,4.21 \%)$ & $6.35 \%$ \\
Legal & 805,083 & $2,337,511$ & $16,936,978$ & $4.75 \%(4.65,4.85 \%)$ & $13.80 \%$ \\
Medical & $7,394,236$ & $16,516,827$ & $184,526,713$ & $4.01 \%(3.83,4.19 \%)$ & $8.95 \%$ \\
\hline
\end{tabular}


the best most carefully geospatially and temporally defined dataset in the world which measures both drug use and mental health outcomes in a synchronized and coordinated manner. Also we believe that the application of modern advanced geospatial analysis to these public health problems is also new and novel and innovative. The limitations of this study relate mainly to its ecological design. For example we had to estimate local use of cannabis by ethnic origin as substate estimates were not available. Similarly individual respondent data from the survey is not available outside of dedicated US research centres and it is clear that access to such data would increase the power of the present investigation. We feel therefore that while the present analysis represents an important contribution to the literature in the field it also provides a strong impetus for further research.

\section{Generalizability}

Given that NSDUH is conducted carefully in a nationally representative manner of the non-institutionalized adult US population the present results are likely to be generalizable to other developed nations. Moreover as it appears that the geospatially observed trends are rooted in the biological processes and mechanisms, what we are seeing at the public health level reflects downstream pharmacological effects from altered biological processes occurring in human neurophysiology. We note that all five of the major racial groups investigated herein showed significant statistical relationships with mental health metrics suggesting cross-racial effects.

\section{Conclusions}

Our interpretation of these results is that all four of the adverse mental health outcomes mapped geotemporospatially by SAMHSA are linked upon formal geospatial analysis with the use of all four of the addictive drugs for which data was available. On testing of single domains of variables against serious mental illness only the drug group was significant, whilst median household income and racial profiling were not. After adjustment for the usual battery of ethnic, drug use and socioeconomic covariates, terms including cannabis were significantly linked with all four domains of mental ill-health from a high level of statistical significance, implying that the widespread deployment of cannabis and cannabinoids for primarily commercial motivations is likely to carry with it major negative mental health implications for the future. Inverse probability weighting was employed to transform data from a purely ecological observational data series to a formal pseudo-randomized design. Highly significant estimates and confidence intervals at inverse probability-weighted robust and mixed effects regression together with large e-Values clearly indicate that these results fulfil the criteria for causal relationships. These epidemiological relationships are consistent with numerous cellular and molecular mechanisms describing cannabis-related neurotoxicity.

We find these results to be of great concern not only for the public health community within the USA but also for the wider international community.

\section{Supplementary Information}

Supplementary information accompanies this paper at https://doi.org/10. 1186/s12889-020-09748-5.

Additional file 1: Supplementary Table 1. Overall Data by Year. Supplementary Table 2. Line Slopes for Cannabis: Mental IIIness Relationships (Fig. 3). Supplementary Table 3. Ethnic Cannabis Consumption Indices Supplementary Table 4. Spatial Panel General Method of Moments Models (Spgm) by Variable Domain.

Supplementary Table 5. Spatial Panel Random Error Maximum Likelihood Models (Spreml) by Variable Domain. Supplementary Table 6. Comparison of Spreml Model Error Structure - Log Likelihood Values. Supplementary Table 7. Deciles of Cannabis Use and Modelled Serious Mental IIIness. Supplementary Table 8. Mixed Effects

Regression Results. Supplementary Table 9. Sensitivity Analysis eValues. Supplementary Table 10. Analysis of Chi Squared Table for Trends by Legal Status.

Additional file 2.

Additional file 3.

Additional file 4.

Additional file 5.

Additional file 6 .

Additional file 7 .

Additional file 8 .

\section{Abbreviations}

Am: -American (Ethnicity); ACS: American Community Survey;

AFE: Attributable Fraction in the Exposed; AFP: Attributable Fraction in the Population; CRAN: Comprehensive R Archive Network; EPSG: European Petroleum Survey Group; e-Value: Expected Value; KKP: Kapoor, Kelejian and Prucha; LCEDI: Local Cannabis Ethnic Daily Index; LCEDPI: Local Cannabis Ethnic Daily Potency Index; LCEPI: Local Cannabis Ethnic Potency Index; MH: Mental Health; MHY: Median Household Income; NH-: Non-Hispanic; NSDUH: National Survey of Drug Use and Health; PR: Prevalence Ratio; SAMH SA: Substance Abuse and Mental Health Services Administration; SMI: Serious Mental IIIness; spgm: Spatial Panel General Moments; spml: Spatial Panel Maximum Likelihood; spreml: Spatial Panel Random Effects Maximum Likelihood; USA: United States of America

\section{Acknowledgements}

Not applicable.

\section{Authors' contributions}

ASR assembled the data, designed and conducted the analyses, and wrote the first manuscript draft. GKH provided technical and logistic support, cowrote the paper, assisted with gaining ethical approval, provided advice on manuscript preparation and general guidance to study conduct. All authors have read and approved the manuscript.

\section{Funding}

No funding was provided for this study. No funding organization played any role in the design and conduct of the study; collection, management, analysis, and interpretation of the data; preparation, review, or approval of the manuscript; and decision to submit the manuscript for publication. 


\section{Availability of data and materials}

No permissions are required to access the data which was used and collated in this study, e.g. NSDUH study. Data including shapefiles and R programming script is made publicly available on the Mendeley Data Archive at this URL: https://doi.org/10.17632/gyckst6rx8.1 . The original SAMH SA shapefiles may be found at https://www.samhsa.gov/data/report/2014-2 016-nsduh-substate-region-shapefile and https://www.samhsa.gov/data/ report/2012-2014-nsduh-substate-region-shapefile.

\section{Ethics approval and consent to participate}

The Human Research Ethics Committee of the University of Western Australia provided ethical approval for the study to be undertaken 7th June 2019 (No. RA/4/20/4724). Ethics approval was not required to access the data in the first instance. However Ethical approval provided permission to access, analyze and publish all the data obtained.

\section{Consent for publication}

Not applicable.

\section{Competing interests}

The authors declare that they have no competing interests.

Received: 27 June 2020 Accepted: 21 October 2020

Published online: 04 November 2020

\section{References}

1. Fergusson DM, Horwood LJ, Beautrais AL. Cannabis and educational achievement. Addiction. 2003:98(12):1681-92.

2. Horwood LJ, Fergusson DM, Hayatbakhsh MR, Najman JM, Coffey C, Patton GC, Silins E, Hutchinson DM. Cannabis use and educational achievement: findings from three Australasian cohort studies. Drug Alcohol Depend. 2010; 110(3):247-53

3. Fergusson DM, Swain-Campbell NR, Horwood LJ. Arrests and convictions for cannabis related offences in a New Zealand birth cohort. Drug Alcohol Depend. 2003;70(1):53-63.

4. Fergusson DM, Boden JM. Cannabis use and later life outcomes. Addiction. 2008;103(6):969-76 discussion 977-968.

5. $\quad$ Dierker L, Selya A, Lanza S, Li R, Rose J. Depression and marijuana use disorder symptoms among current marijuana users. Addict Behav. 2018;76: $161-8$.

6. Filbey FM, Aslan S, Lu H, Peng SL. Residual effects of THC via novel measures of brain perfusion and metabolism in a large Group of Chronic Cannabis Users. Neuropsychopharmacology. 2018:43(4):700-7.

7. Gobbi G, Atkin T, Zytynski T, Wang S, Askari S, Boruff J, Ware M, Marmorstein $\mathrm{N}$, Cipriani A, Dendukuri N, et al. Association of Cannabis use in adolescence and risk of depression, anxiety, and Suicidality in young adulthood: a systematic review and meta-analysisCannabis use in adolescence and risk of depression, anxiety, and Suicidality in young AdulthoodCannabis use in adolescence and risk of depression, anxiety, and Suicidality in young adulthood. JAMA Psychiatry. 2019;76(4):426-34

8. Hanna RC, Perez JM, Ghose S. Cannabis and development of dual diagnoses: a literature review. Am J Drug Alcohol Abuse. 2017:43(4):442-55.

9. Marwaha S, Winsper C, Bebbington P, Smith D. Cannabis use and hypomania in young people: a prospective analysis. Schizophr Bull. 2018; 44(6):1267-74

10. Bartoli F, Crocamo C, Carra G. Cannabis use disorder and suicide attempts in bipolar disorder: a meta-analysis. Neurosci Biobehav Rev. 2019;103:14-20.

11. Otten R, Huizink AC, Monshouwer K, Creemers HE, Onrust S. Cannabis use and symptoms of anxiety in adolescence and the moderating effect of the serotonin transporter gene. Addict Biol. 2017;22(4):1081-9.

12. Duperrouzel J, Hawes SW, Lopez-Quintero C, Pacheco-Colon I, Comer J, Gonzalez R. The association between adolescent cannabis use and anxiety: a parallel process analysis. Addict Behav. 2018;78:107-13.

13. Ecker AH, Buckner JD. Cannabis-related problems and social anxiety: the Mediational role of post-event processing. Substance Use Misuse. 2018; 53(1):36-41

14. Kimbrel NA, Newins AR, Dedert EA, Van Voorhees EE, Elbogen EB, Naylor JC, Ryan Wagner H, Brancu M, Workgroup VAM-AM, Beckham JC et al: Cannabis use disorder and suicide attempts in Iraq/Afghanistan-era veterans. J Psychiatr Res 2017, 89:1-5.
15. Waterreus A, Di Prinzio P, Badcock JC, Martin-Iverson M, Jablensky A, Morgan VA. Is cannabis a risk factor for suicide attempts in men and women with psychotic illness? Psychopharmacology. 2018;235(8):2275-85.

16. Fergusson DM, Poulton R, Smith PF, Boden JM. Cannabis and psychosis. BMJ. 2006;332(7534):172-5.

17. Fergusson DM, Horwood LJ, Swain-Campbell NR. Cannabis dependence and psychotic symptoms in young people. Psychol Med. 2003;33(1):15-21.

18. Gage SH, Hickman M, Zammit S. Association between Cannabis and psychosis: epidemiologic evidence. Biol Psychiatry. 2016;79(7):549-56.

19. Marconi A, Di Forti M, Lewis CM, Murray RM, Vassos E. Meta-analysis of the association between the level of Cannabis use and risk of psychosis. Schizophr Bull. 2016;42(5):1262-9.

20. Nielsen SM, Toftdahl NG, Nordentoft M, Hjorthoj C. Association between alcohol, cannabis, and other illicit substance abuse and risk of developing schizophrenia: a nationwide population based register study. Psychol Med. 2017;47(9):1668-77.

21. Ortiz-Medina MB, Perea M, Torales J, Ventriglio A, Vitrani G, Aguilar L, Roncero C. Cannabis consumption and psychosis or schizophrenia development. Int J Social Psychiatry. 2018;64(7):690-704.

22. Starzer MSK, Nordentoft M, Hjorthoj C. Rates and predictors of conversion to schizophrenia or bipolar disorder following substance-induced psychosis. Am J Psychiatry. 2018;175(4):343-50.

23. Vaucher J, Keating BJ, Lasserre AM, Gan W, Lyall DM, Ward J, Smith DJ, Pell JP, Sattar N, Pare G, et al. Cannabis use and risk of schizophrenia: a Mendelian randomization study. Mol Psychiatry. 2018;23(5):1287-92.

24. Fergusson DM, Boden JM, Horwood L. Cannabis use and other illicit drug use: testing the cannabis gateway hypothesis. Addiction. 2006;101(4):556-69.

25. Substance Abuse and Mental Health Services Administration: About Us [https://www.samhsa.gov/about-us]. Accessed 20 Aug 2020

26. National Institute of Drug Abuse: 2016-2020 Strategic Plan [https://www. drugabuse.gov/about-nida/strategic-plan/nidas-mission]. Accessed 20 Aug 2020.

27. McCantz-Katz E: 2017 Annual report snippets, NSDUH, SAMHSA, USA DHHS - selected streamlined trends. In. Edited by Substance Abuse and Mental Health Services Administration US Department of Health and Human Services, vol. 1. Rockville, Maryland: SAMHSA, DHHS, USA; 2018: 1-78.

28. Volkow ND, Baler RD, Compton WM, Weiss SR. Adverse health effects of marijuana use. N Engl J Med. 2014;370(23):2219-27.

29. Volkow ND, Hampson AJ, Baler RD. Don't worry, be happy: Endocannabinoids and Cannabis at the intersection of stress and reward. Annu Rev Pharmacol Toxicol. 2017:57:285-308.

30. Volkow ND, Swanson JM, Evins AE, DeLisi LE, Meier MH, Gonzalez R, Bloomfield MA, Curran HV, Baler R. Effects of Cannabis use on human behavior, including cognition, motivation, and psychosis: a review. JAMA Psychiatry. 2016;73(3):292-7.

31. Bloomfield MA, Ashok AH, Volkow ND, Howes OD. The effects of Delta9tetrahydrocannabinol on the dopamine system. Nature. 2016;539(7629):369-77.

32. Compton WM, Volkow ND, Lopez MF. Medical marijuana Laws and Cannabis use: intersections of health and policy. JAMA Psychiatry. 2017;74(6):559-60.

33. Volkow ND, Han B, Compton WM, McCance-Katz EF. Self-reported medical and nonmedical Cannabis use among pregnant women in the United States. JAMA. 2019:322(2):167-9.

34. Fergusson DM, Boden JM, Horwood $\amalg$. Psychosocial sequelae of cannabis use and implications for policy: findings from the Christchurch health and development study. Soc Psychiatry Psychiatr Epidemiol. 2015;50(9):1317-26.

35. van Ours JC, Williams J, Fergusson D, Horwood LJ. Cannabis use and suicidal ideation. J Health Econ. 2013;32(3):524-37.

36. Marie D, Fergusson DM, Boden JM. Links between ethnic identification, cannabis use and dependence, and life outcomes in a New Zealand birth cohort. Australian New Zealand J Psychiatry. 2008;42(9):780-8.

37. Fergusson DM, Boden JM. Cannabis use and adult ADHD symptoms. Drug Alcohol Depend. 2008:95(1-2):90-6.

38. Fergusson DM, Horwood LJ, Swain-Campbell N. Cannabis use and psychosocial adjustment in adolescence and young adulthood. Addiction. 2002:97(9):1123-35.

39. Reece AS, Hulse GK. Cannabis consumption patterns parallel the east-west gradient in Canadian neural tube defect incidence: an ecological study. Global Pediatric Health. 2019; In Press.

40. Reece AS. Chronic toxicology of cannabis. Clin Toxicol. 2009:47(6):517-24.

41. 2014-2016 NSDUH Substate Region Shapefile [https://www.samhsa.gov/ data/report/2014-2016-nsduh-substate-region-shapefile]. Accessed 20 Aug 2020. 
42. 2010-2012 NSDUH Substate Region Shapefile [https://www.samhsa.gov/ data/report/2010-2012-nsduh-substate-region-shapefile-zip-file-download] Accessed 20 Aug 2020

43. Hedden S, Gfroerer J, Barker P, Smith S, Pemberton MR, Saavedra LM, Forman-Hoffman VL, Ringeisen H, Novak SP: Comparison of NSDUH Mental Health Data and Methods with Other Data Sources. In: CBHSQ Data Review. edn. Rockville (MD); 2012: 1-19.

44. ElSohly MA, Mehmedic Z, Foster S, Gon C, Chandra S, Church JC. Changes in Cannabis potency over the last 2 decades (1995-2014): analysis of current data in the United States. Biol Psychiatry. 2016;79(7):613-9.

45. ElSohly MA, Ross SA, Mehmedic Z, Arafat R, Yi B, Banahan BF 3rd. Potency trends of delta9-THC and other cannabinoids in confiscated marijuana from 1980-1997. J Forensic Sci. 2000;45(1):24-30.

46. Tobler W. A Computer Movie Simulating Urban Growth in the Detroit Region. Economic Geography. 1970;46(Supplement):234-40.

47. Kapoor M, Kelejian HH, Prucha IR. Panel data models with spatially correlated error components. J Econ. 2007;140(1):97-130.

48. VanderWeele TJ, Ding P. Sensitivity analysis in observational research: introducing the E-value. Ann Intern Med. 2017;167(4):268-74.

49. VanderWeele TJ, Mathur MB. Commentary: developing best-practice guidelines for the reporting of E-values. Int J Epidemiol. 2020. https://doi. org/10.1093/ije/dyaa094.

50. VanderWeele TJ, Martin JN, Mathur MB: E-values and incidence density sampling. Epidemiology 2020.31(6):e51-e52. https://doi.org/10.1097/ede. 0000000000001238.

51. VanderWeele TJ, Ding P. Sensitivity analysis in observational research: introducing the E-value. Ann Intern Med. 2017;167(4):268-74. https://doi.org/ 10.7326/m16-2607.

52. VanderWeele TJ, Ding P, Mathur M. Technical considerations in the use of the E-value. J Causal Inference. 2019;7(2):1-11.

53. Mathur MB, Ding P, Riddell CA, VanderWeele TJ. Web site and R package for computing E-values. Epidemiology. 2018;29(5):e45-7.

54. National Survey of Drug Use and Health 2018, NSDUH [https://www.samhsa. gov/data/all-reports]. Accessed 20 Aug 2020

55. Hill AB. The environment and disease: association or causation? Proc R Soc Med. 1965;58:295-300.

56. Murphy SK, Itchon-Ramos N, Visco Z, Huang Z, Grenier C, Schrott R, Acharya K, Boudreau MH, Price TM, Raburn DJ, Corcoran DL, Lucas JE, Mitchell JT, McClernon FJ, Cauley M, Hall BJ, Levin ED, Kollins SH. Cannabinoid exposure and altered DNA methylation in rat and human sperm. Epigenetics. 2018; 13(12):1208-21. https://doi.org/10.1080/15592294.2018.1554521.

57. DiNieri JA, Wang X, Szutorisz H, Spano SM, Kaur J, Casaccia P, Dow-Edwards D, Hurd YL. Maternal cannabis use alters ventral striatal dopamine D2 gene regulation in the offspring. Biol Psychiatry. 2011;70(8):763-9.

58. Szutorisz H, DiNieri JA, Sweet E, Egervari G, Michaelides M, Carter JM, Ren Y, Miller ML, Blitzer RD, Hurd YL. Parental THC exposure leads to compulsive heroin-seeking and altered striatal synaptic plasticity in the subsequent generation. Neuropsychopharmacol. 2014;39(6):1315-23.

59. Watson CT, Szutorisz H, Garg P, Martin Q, Landry JA, Sharp AJ, Hurd YL. Genome-wide DNA methylation profiling reveals epigenetic changes in the rat nucleus Accumbens associated with cross-generational effects of adolescent THC exposure. Neuropsychopharmacol. 2015;40(13):29933005 .

60. Schrott R, Acharya K, Itchon-Ramos N, Hawkey AB, Pippen E, Mitchell JT, Kollins SH, Levin ED, Murphy SK. Cannabis use is associated with potentially heritable widespread changes in autism candidate gene DLGAP2 DNA methylation in sperm. Epigenetics. 2020;15(1-2):161-73. https://doi.org/10. 1080/15592294.2019.1656158.

61. Eisch AJ, Barrot M, Schad CA, Self DW, Nestler EJ. Opiates inhibit neurogenesis in the adult rat hippocampus. Proc Natl Acad Sci U S A. 2000; 97(13):7579-84.

62. Ising C, Venegas C, Zhang S, Scheiblich H, Schmidt SV, Vieira-Saecker A, Schwartz S, Albasset S, McManus RM, Tejera D, et al. NLRP3 inflammasome activation drives tau pathology. Nature. 2019:575(7784):669-73.

63. Cutando L., Maldonado R., Ozaita A.: Microglial Activation and Cannabis Exposure. In: Handbook of Cannabis and Related Pathologies: Biology, Pharmacology, Diagnosis and Treatment. Volume 1, edn. Edited by Preedy V. New York: Academic Press; 2017: 401-412.

64. Reece AS, Norman A, Hulse GK. Cannabis exposure as an interactive cardiovascular risk factor and accelerant of organismal ageing: a longitudinal study. BMJ Open. 2016;6(11):e011891.
65. Wang J, Yuan W, Li MD. Genes and pathways co-associated with the exposure to multiple drugs of abuse, including alcohol, amphetamine/ methamphetamine, cocaine, marijuana, morphine, and/or nicotine: a review of proteomics analyses. Mol Neurobiol. 2011:44(3):269-86.

66. Foldy C, Malenka RC, Sudhof TC. Autism-associated neuroligin-3 mutations commonly disrupt tonic endocannabinoid signaling. Neuron. 2013;78(3): 498-509.

67. Anderson GR, Aoto J, Tabuchi K, Foldy C, Covy J, Yee AX, Wu D, Lee SJ, Chen L. Malenka RC et al: beta-Neurexins control neural circuits by regulating synaptic Endocannabinoid signaling. Cell. 2015;162(3):593-606.

68. Wang $\mathrm{H}$. Endocannabinoid Mediates Excitatory Synaptic Function of $\beta$ Neurexins. Commentary: $\beta$-Neurexins Control Neural Circuits by Regulating Synaptic Endocannabinoid Signaling. Front Neurosci. 2016;10:203.

69. Zalesky A, Solowij N, Yucel M, Lubman DI, Takagi M, Harding IH, Lorenzetti V, Wang R, Searle K, Pantelis C, et al. Effect of long-term cannabis use on axonal fibre connectivity. Brain. 2012;135(Pt 7):2245-55.

70. Tortoriello G, Morris CV, Alpar A, Fuzik J, Shirran SL, Calvigioni D, Keimpema E, Botting CH, Reinecke K, Herdegen T, et al. Miswiring the brain: Delta9tetrahydrocannabinol disrupts cortical development by inducing an SCG10/ stathmin-2 degradation pathway. EMBO J. 2014;33(7):668-85.

71. Reece AS, Hulse GK. Chromothripsis and epigenomics complete causality criteria for cannabis- and addiction-connected carcinogenicity, congenital toxicity and heritable genotoxicity. Mutat Res. 2016;789:15-25.

72. Tahir SK, Zimmerman AM. Influence of marihuana on cellular structures and biochemical activities. Pharmacol Biochem Behav. 1991;40(3):617-23.

73. Zimmerman AM, Raj AY. Influence of cannabinoids on somatic cells in vivo. Pharmacology. 1980;21(4):277-87.

74. Alpar A, Tortoriello G, Calvigioni D, Niphakis MJ, Milenkovic I, Bakker J, Cameron GA, Hanics J, Morris CV, Fuzik J, et al. Endocannabinoids modulate cortical development by configuring Slit2/Robo1 signalling. Nat Commun. 2014;5:4421

75. Cardenas A, Villalba A, de Juan RC, Pico E, Kyrousi C, Tzika AC, TessierLavigne M, Ma L, Drukker M, Cappello S, et al. Evolution of cortical neurogenesis in amniotes controlled by Robo signaling levels. Cell. 2018; 174(3):590-606 e521.

76. Yeh ML, Gonda Y, Mommersteeg MT, Barber M, Ypsilanti AR, Hanashima C, Parnavelas JG, Andrews WD. Robo1 modulates proliferation and neurogenesis in the developing neocortex. J Neurosci. 2014;34(16):5717-31.

77. Russo C, Ferk F, Misik M, Ropek N, Nersesyan A, Mejri D, Holzmann K, Lavorgna M, Isidori M, Knasmuller S. Low doses of widely consumed cannabinoids (cannabidiol and cannabidivarin) cause DNA damage and chromosomal aberrations in human-derived cells. Arch Toxicol. 2019;93(1): 179-88. https://doi.org/10.1007/s00204-018-2322-9.

78. Zimmerman AM, Zimmerman S., Raj A.Y.: Effects of Cannabinoids on spermatogenesis in mice. In: Marihuana and medicine. edn. Edited by Nahas G.G., Sutin K.M., Harvey D.J., Agurell S. Totowa, N. J, USA.: Humana Press; 1999: 347-358.

79. Zumbrun EE, Sido JM, Nagarkatti PS, Nagarkatti M. Epigenetic regulation of immunological alterations following prenatal exposure to marijuana cannabinoids and its long term consequences in offspring. J Neurolmmune Pharmacol. 2015;10(2):245-54.

80. Hwang YS, Kim YJ, Kim MO, Kang M, Oh SW, Nho YH, Park SH, Lee J. Cannabidiol upregulates melanogenesis through $\mathrm{CB} 1$ dependent pathway by activating p38 MAPK and p42/44 MAPK. Chem Biol Interact. 2017;273: 107-14.

81. Shoyama Y, Sugawa C, Tanaka H, Morimoto S. Cannabinoids act as necrosisinducing factors in Cannabis sativa. Plant Signal Behav. 2008;3(12):1111-2.

82. Hughes V. Epigenetics: the sins of the father. Nature. 2014;507(7490):22-4.

83. Reece AS, Hulse GK. Epidemiological associations of various substances and multiple cannabinoids with autism in USA. Clinical Pediatrics: Open Access. 2019:4(2):1-20.

84. Reece AS, Hulse GK. Effect of Cannabis legalization on US autism incidence and medium term projections. Clinical Pediatrics: Open Access. 2019;4(2):1-17.

85. Reece AS, Hulse GK. Gastroschisis and autism-dual canaries in the Californian coalmine. JAMA Surg. 2019;154(4):366-7.

86. Reece AS, Hulse GK: Impacts of Cannabinoid Epigenetics on Human Development: Reflections on Murphy et. al. 'Cannabinoid Exposure and Altered DNA Methylation in Rat and Human Sperm' Epigenetics 2018; 13: 1208-1221. Epigenetics 2019:1-16.

87. Brents L.: Correlates and consequences of Prenatal Cannabis Exposure (PCE): Identifying and Characterizing Vulnerable Maternal Populations and 
Determining Outcomes in Exposed Offspring In: Handbook of Cannabis and Related Pathologies: Biology, Pharmacology, Diagnosis and Treatment. Volume 1, edn. Edited by Preedy V.R. London: Academic Press; 2017: 160170.

88. Casey BJ, Cohen JD, Jezzard P, Turner R, Noll DC, Trainor RJ, Giedd J, Kaysen D, Hertz-Pannier L, Rapoport JL. Activation of prefrontal cortex in children during a nonspatial working memory task with functional MRl. Neuroimage. 1995;2(3):221-9.

89. Tervo-Clemmens B, Simmonds D, Calabro FJ, Day NL, Richardson GA, Luna B. Adolescent cannabis use and brain systems supporting adult working memory encoding, maintenance, and retrieval. Neuroimage. 2018;169:496-509.

90. Smith AM, Mioduszewski O, Hatchard T, Byron-Alhassan A, Fall C, Fried PA. Prenatal marijuana exposure impacts executive functioning into young adulthood: an fMRI study. Neurotoxicol Teratol. 2016;58:53-9.

91. Smith AM, Longo CA, Fried PA, Hogan MJ, Cameron I. Effects of marijuana on visuospatial working memory: an fMRI study in young adults. Psychopharmacology. 2010;210(3):429-38.

92. Smith AM, Fried PA, Hogan MJ, Cameron I. Effects of prenatal marijuana on visuospatial working memory: an fMRI study in young adults. Neurotoxicol Teratol. 2006;28(2):286-95.

93. Smith AM, Fried PA, Hogan MJ, Cameron I. Effects of prenatal marijuana on response inhibition: an fMRI study of young adults. Neurotoxicol Teratol. 2004;26(4):533-42.

94. Smith A, Fried P, Hogan M, Cameron I. The effects of prenatal and current marijuana exposure on response inhibition: a functional magnetic resonance imaging study. Brain Cogn. 2004:54(2):147-9.

\section{Publisher's Note}

Springer Nature remains neutral with regard to jurisdictional claims in published maps and institutional affiliations.

Ready to submit your research? Choose BMC and benefit from:

- fast, convenient online submission

- thorough peer review by experienced researchers in your field

- rapid publication on acceptance

- support for research data, including large and complex data types

- gold Open Access which fosters wider collaboration and increased citations

- maximum visibility for your research: over $100 \mathrm{M}$ website views per year

At BMC, research is always in progress.

Learn more biomedcentral.com/submissions 